\title{
BLOOD DONATION BEHAVIOUR AND BELIEFS AMONG A SAMPLE OF HIGH SCHOOL STUDENTS IN MMABATHO
}

\author{
K Mwaba and MJ Keikelame
}

\begin{abstract}
This study was aimed at estabtishing the exient of blood donation and beliefs about donating blood among high school students in Mmabatho. A random sample of 40 Standard 10 students 20 males, 20 females, mean age $=20.8$ years) was selected to paricipate in the stuty. A stmuctured questionnaire was used to determine blood donation behaviour and accompanying beliefs. The results showed that atthough 80 percent of the participants belleved that donating blood was important anly 17.5 percent had actually ever donated blood. The dala also showed that donating blood was a health risk. or were uncertain if donating blood was safe. It is recommended that public appeals for blood donors should include information to dispel myths about dangers of donating. blood.
\end{abstract}

\section{INTRODUCTION}

Donated blood is used in many emergency medical procedures and an adequate supply of donated blood is a vital part of any health service. Hospital blood banks, which are responsible for maintaining adequate supplies of blood, rely on the voluntary and active participation of members of the public in donating blood.

Recently, health workers have expressed concern about the declining supply of blood in blood banks of South Africa. It seems that fewer people are donating blood than in the past and those who donate are doing so less frequently. According to Professor Harry Seftel of Wits Medical School, South Africa "needs donor blood more than ever before as a result of the ongoing criminal violence and the high rate of car accidents" (Mokone, 1994, p.7). It is important therefore to seek an understanding of beliefs and behaviour pertaining to blood donation.
Numerous studies have been conducted to investigate various aspects of blood donation behaviour. Some researchers have focused on attitudes towards blood donation (Macaskill, Hastings, McNeill, \& Gillon, 1989; Okpara, 1989) with a view to behaviour. Other researchers have been concerned with establishing people's perceptions about blood donation and the risk of HIV infections (Bhopal, McEwan, Madhok, \& McCallum, 1992; Lo Bello, 1990).

Although there is some evidence that there may be characteristics distinguishing blood donors from non-donors (Mathiesen, Bordthagen, Edvardsen, \& Grunnet, 1989), the literature on blood donation indicates that attitudes toward donation influence behaviour only in an indirect maner.

A study conducted by Breckler and Wiggins (1989) found that affect was more strongly correlated with the number of prior blood donations than was cognition. This finding was interpreted as indicating that emotional factors may play an important role in blood donation behaviour. Bagozzi (1987) found that beliefs about the negative consequences of donating blood differentiated those who intended to donate blood from those who indicated no such intention. It was concluded that attitudes toward blood donation may also depend on the extent of prior experience with focal behaviour and the degree of confidence and consistency between the affective and cognitive responses.

The results of these empirical studies on blood donation are consistent with findings in social psychology which indicate that attitudes may rarely influence a person's behaviour directly.

\section{PURPOSE OF STLDY}

The purpose of this study was to determine blood donation behaviour, willingness to donate blood, and beliefs about donation among a sample of high school students. The study was descriptive and aimed at establishing behaviour and beliefs about blood donation.

\section{METHODOLOGY}

The participants in the study were a randomly selected sample of 20 males and 20 females in
Standard 10 at a high school in Mmabatho. The mean age was 20.8 years.

The data were collected using a questionnaire divided into three parts. The first part was designed to collect biographical data such as sex, age, religious affiliation, etc. The second part of the instrument consisted of a six-item structured questionnaire to establish blood donation behaviour of the respondents: past, present and future donation behaviour, source and knowledge of blood donation. The third part was an eight-item structured questionnaire dealing with beliefs about donating blood such as: Is blood donation painful? Do you think a person can catch a disease through donating blood? etc. The items of the questionnaire were adapted from instruments that have been used to study blood donation behaviour (Breckler \& Wiggins, 1989).

\section{RESULTS}

All the participants indicated that they were Christians: 87:5 percent Protestants, 7.5 percent Jehovah's Witnesses and 5 percent Roman Catholic. The data showed that although 80 percent of respondents believed that donating blood was important, only 17.5 percent of the participants had ever donated blood. When asked if they would be willing to donate blood in the future 52.5 percent of the participants indicated a willingness while 17.5 percent declined. Thirty percent of the participants were not sure.

Regarding reasons for not donating blood, the most frequently mentioned reasons were fear of losing blood and an adverse effect on the donor's body. Few participants mentioned reasons such as lack of time, fear of pain and detection of disease. The reasons given by participants are shown in Table 1.

When asked to indicate the source of information about blood donation, 70 percent of the respondents reported that nurses were the main source, followed by teachers $(20 \%)$, and doctors (5\%).

The data on beliefs about blood donation indicated that there was widespread uncertainly among the participants. Participants were asked to respond to belief statements about blood donation using "Yes", 


$\begin{aligned} & \text { TABLE 1: Participants' Reasons for } \\ & \text { Not Donating Blood }\end{aligned}$
Total Number of Respondents (N=40)
Reasons
\% of Respondents
Fear of Losing Blood

"No" and "Not Sure" response categories. When asked if they believed that one could catch a disease through donating blood, 37.5 percent of the respondents expressed agrcement while 22.5 percent disagreed. The remaining $40 \%$ indicated that they were not sure.

Participants were also asked if they believed donating blood could make a person unhealthy. Almost 34 percent of the respondents indicate that they were not sure; 35 percent agreed, and 27.5 percent disagreed that blood donation posed a risk to their health.

The data also showed that 12.5 percent believed that donating blood was harmful, 42.5 percent that it was not harmful, and 45 percent were not sure.

To test the view that reluctance to donate blood may be due to a belief that blood donation is time consuming and painful, respondents were asked to respond to these items.

The results showed that 17.5 percent of the participants believed that it was painful while 2.5 percent believed that it was time consuming. However, a large proportion of respondents were not sure if blood donation was painfulor time consuming ( 45 percent and 57.5 percent respectively). Table 2 shows participants' beliefs about blood donation.
TABLE 2: Participants' Beliefs about Blood Donation Total Number of Respondents $(N=40)$

Belleis

Donating Blood is important Yes $\%$ of Respondents No Not Sure

Can be Infecled with Disease

80

Body can become Unhealthy

37.5

5

15

37.5
35

22.5

27.5

30

17.5

12.5

Harmful

2.5

42.5

40

\section{CONCLUSION AND} RECOMMENDATIONS

The results of the present study indicated that most high school students may be aware of the importance of donating blood. Eighty percent of the participants sampled indicated that they considered donating blood to be important. While this may sound encouraging, the data also showed that only 17.5 percent of the participants had ever donated blood.

The data on beliefs about blood donation showed that many respondents held fears about the risks of donating blood such as catching a disease or causing harm to one's health. It seems, therefore, that reluctance to donate blood may not be due to lack of appreciating or understanding its imporance. Rather, the problem may be that many young people (perhaps even older ones) believe that donating blood is a health risk in terms of exposing one to diseases and/or adversely affecting one's health.

The findings of the present study suggest that efforts aimed at recruiting blood donors should not only make appeals stressing the importance of donating blood. Health workers must attempt to dispel the myths about dangers of donating blood which, according to findings of this study, are the basis for poor response to blood donation appeals. Nurses, who appear to be the main source of public information about blood donation, can play a major role in changing attitudes of young people towards blood donation through carefully considered educational programmes.

\section{REFERENCES}

Bagozzi, R.P. (1987). Altitudes, intentions and behaviour. Lowmal of Personality and Social Psychology, 13, 9-31.

Bhopal, R.S, McEwan, R.T, Madhok, R., \& McCallum, A. (1992). Perceptions about blood donation, transfusion and the risk of HIV infections. Loumal of Medical Research Council. 4(1), 43-52.

Breckler, S.J., \& Wiggins, E.C.(1989). Scales for the measurement of attitudes towards donation. Joumal of Medical Research Council, 29(5), 401-404.

Lo Bello, S.G. (1990). Differences between blood donors and non-donors in aids related attitudes. Loumal of Medical_Research_Council, 66(3). 867-870.

Macaskill, S.G. Hastings, G.B. McNelli, R.E., \& Gillon, J. (1989). Scotish attitudes to blood donation and aids. Loumal of Medical Research Council 298 1012-1014.

Mokone, T. (1994, November 3). Rising dentand for blood. The Stan, p.7.

Mathiesen, O., Bordthagen, U.A., Edvardsen, I., \& Grunnet, N. (1989). Characteristics of first time blood donors and their morives. Joumal of Medical Research Council. 151(47), 3155-3157.

Okpara, R.A. (1989). Attitudes of Nigerians towards blood donation and blood transfusion. Loumal of Medical Reseanch Council. 41(1), 89-93.

Kelvin Mwaba, Ph.D
(Senior Lecturer) and
Mphoe J.Keikelame, B.Soc.Sc.
(Postgraduate Student)
Department of Psychology
UNIVERSITY OF THE NORTH WEST
MMABATHO

